DOI 10.22460/infinity.v6i2.p183-194

\title{
ANALYSIS OF STUDENTS' MATHEMATICAL COMMUNICATION ABILITY BY USING COOPERATIVE LEARNING TALKING STICK TYPE
}

\author{
Dwi Maulida Sari \\ Universitas Pendidikan Indonesia, J1. Setiabudi No.229, Bandung, West Java, Indonesia \\ dwimaulida20@student.upi.edu
}

Received: May 12, 2017; Accepted: July 02, 2017

\begin{abstract}
This research aims to describe the students' mathematical communication ability by using cooperative learning talking stick type. This research conducted at one of junior high school in Asahan-North Sumatera- North Sumatera. This research used posttest experimental class design as the method to obtain data. The indicators used to measure mathematical communication ability in this research arranged in three, as follows: 1) the ability of explaining a mathematical problem into figure; 2) the ability to explain mathematical problem situations by own words; 3) the ability of stating a mathematical problem in writing into mathematical models and doing calculation to solve the problem. The result found from this research is there are the differences in the students' way of answering the problem even though the learning model and the instrument used is same.
\end{abstract}

Keywords: Cooperative Learning, Mathematical Communication Ability, Talking Stick Type

\begin{abstract}
Abstrak
Penelitian ini bertujuan untuk mendeskripsikan kemampuan komunikasi matematis siswa dengan pembelajaran kooperatif tipe talking stick. Penelitian ini diadakan di salah satu sekolah menengah pertama di Asahan-- Sumatera Utara. Penelitian ini menggunakan desain kelas eksperimen dengan posttes untuk mengumpulkan data. Indikator yang digunakan untuk mengukur kemampuan komunikasi matematis dalam penelitian iniyaitu: 1) kemampuan untuk menjelaskan persoalan matematika kedalam bentuk gambar/ visual; 2) kemampuan untuk menjelaskan persoalan matematika kedalam bahasa sendiri; 3) kemampuan untuk menentukan dan membuat model matematika yang sesuai dari persoalan matematika tertulis serta melakukan perhitungan untuk menyelesaikan persoalan matematika tersebut. Hasil dari penelitian ini adalah terdapat perbedaan karakteristik cara siswa menjawab soal, walaupun model pembelajaran dan instrumen yang digunakan sama.
\end{abstract}

Kata Kunci: Kemampuan Komunikasi Matematis, Pembelajaran Kooperatif, Tipe Talking Stick.

How to Cite: Sari, M. D. (2017). Analysis of Students' Mathematical Communication Ability by Using Cooperative Learning Talking Stick Type. Infinity, 6 (2), 183-194. doi:10.22460/infinity.v6i2.p183-194 


\section{INTRODUCTION}

Educational researchers state that students need to learn effectively how to communicate their thinking both orally and in writing (National Middle School Association [NMSA], 2004; Secretary's Commision on Achieving Necessary Skills [SCANS], 1991; National Council of Teachers of Mathematics [NCTM], 1989, 2000; Cobb, Yackel, \& Wood, 1992).

Kist (Clark, Jacobs, Pittman, \& Borko, 2005) stated that in general effective communication ability should be possessed by students in all subject matters and not only in mathematics, that is communication is important in all subject also in life. Mathematics as a vehicle for education, not only can be used to achieve one goal such as to educate students but can also form the personality of students and develop certain skills. Mathematics is abstract and deductive science, mathematics is a knowledge that studying patterns, shapes, and structures and mathematics are the human activity. According to Permendiknas No. 22 (2006) the purpose of learning mathematics are:

“(1) memahami konsep matematika. Menjelaskan keterkaitan antar konsep dan mengaplikan konsep atau algoritma, secara luwes, akurat, efisien dan tepat dalam pemecahan masalah, (2) menggunakan penalaran pada pola dan sifat, melakukan manipulasi matematika dalam membuat generalisasi, menyusun bukti, atau menjelaskan gagasan dan pernyataan matematika, (3) memecahkan masalah yang meliputi kemampuan memahami masalah, merancang model matematika, menyelesaikan model dan menafsirkan solusi yang diperoleh, (4) mengkomunikasikan gagasan dengan simbol, tabel, diagram atau media lain untuk memperjelas keadaan dan masalah, (5) memiliki sikap menghargai matematika dalam kehidupan, yaitu memiliki rasa ingin tahu, perhatian, dan minat dalam mempelajari matematika serta sikap ulet dan percaya diri dalam pemecahan masalah".

So, as said by the Permendiknas No.22 that one purpose of learning mathematics is communicate ideas with symbols, tables, diagrams or other media to clarify the situation and problems. Pugalee (2001) also state that to improve students' mathematical communication ability need to motivated them to give relevant reason on their answer. Students were able to understand mathematics concepts being learned meaningfully.It's clearly showing that the ability of mathematics communication is needed.

National Council of Teachers of Mathematics (2000) state that mathematical communication abilities include expressing mathematical thought by using mathematical language clearly, precisely, and succinctly, understanding others' mathematical equations and concepts (Lin, Shann, \& Lin, 2008) and evaluating others' mathematical concepts by asking meaningful questions and explaining the reasons for others' incorrect mathematical thought.

In general, the communication can be interpreted as the process to achieve the purpose of communication itself which is to conveying a message from one person to another either directly (orally) or indirectly. NCTM (2000) state that through communication, ideas become objects of reflection, refinement, discussion, and amendment. The communication process also helps build meaning and permanence for ideas and makes them public. The process of learning and teaching also contributes to developing students' communication ability, by convey their ideas and opinions teachers can find out how much the students learned and understand the material. Students are challenged to think and give a reason about mathematics also communicate the results of their minds to others orally or in writing, they learn to be clear and convincing and this is the process of communication. 
Communication in mathematics is called mathematical communication ability is the ability to deliver something that is known through speech or writing dialogue about the concepts, formulas, or problem-solving strategies in mathematics. The mathematical communication ability reflect students' understanding. The concept or information of mathematics given by a teacher to the student, or students gets it by themselves that is when the transformation of mathematical information from the communicator to the communicant happen. In mathematics, the quality of interpretation and the response was often a special problem. It is as a result of characteristics of the mathematics itself which loaded with terms and symbols. Therefore, the mathematical communication ability became a special requirement in learning mathematics. It is happen because mathematics language different from the mother language, Layzer (Baroody, 1993) said the language of mathematics is fundamentally different from natural languages, though, in that it describes ideal situations rather than ordinary situations.

The description above shows the importance of mathematical communication ability in learning mathematics, it has an important role in building the knowledge of mathematics and expresses mathematical ideas from students' various perspectives. Through communication, students can submit their ideas to the teacher and to other students.

Based on preliminary observations in class VII on one junior high school at Asahan-North Sumatera obtained that the lesson is still centered on the teacher, not on students. The result in this kind of learning made students passive in developing their minds or deliver their idea. From this preliminary observation also found that students' mathematical communication ability is still low.For example, problem number one; Write down every sentence below into a mathematical expression by using a variable. (a) The result from multiple of two natural numbers and add it by 2 is 9, (b) Amount of Ikhsan and Bayu books is 11, while the difference of their books is 1 .

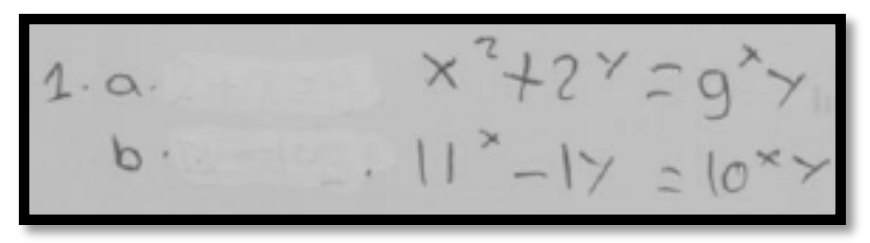

Figure 1. One of Student's Answer for Problem Number 1

For problem number one, from the figure can be seen that student can not state the model for the two natural number, student think the two natural number on as the number and the other as the power of it and also give power to number 2, this might happen because student remember about exponential that they learn before or maybe students did not understand the problem or student ability to state the words into mathematical expression is low. It also happens in b question, student confused to state the sum and also the difference of Ikhsan and Bayu book. This show the student ability in state words into mathematical expression is in an unsatisfactory manner.

For the problem number two the problem is state $5 \frac{1}{2}$ into figure form (you can choose the shape that you want). 


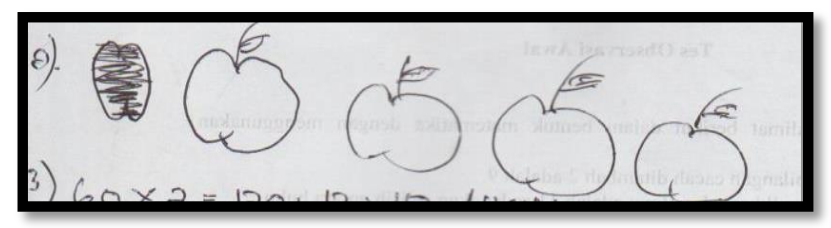

Figure 2. Student's Answer to Problem No.2

Some students are able to state $5 \frac{1}{2}$ in right figure form but some are not. Show in the figure above student wants to state the problem in apple form, but students still confused how to divide the apple in right half form, maybe that is student erase the first figure. It also show that students ability to make the right figure from is still low.

The problem number three is: a company will deliver package to their 60 employees, which consists of 2 bottles of syrup and 12 pieces of instant noodles. Explain how many dozen syrup and instant noodles are required by the company.

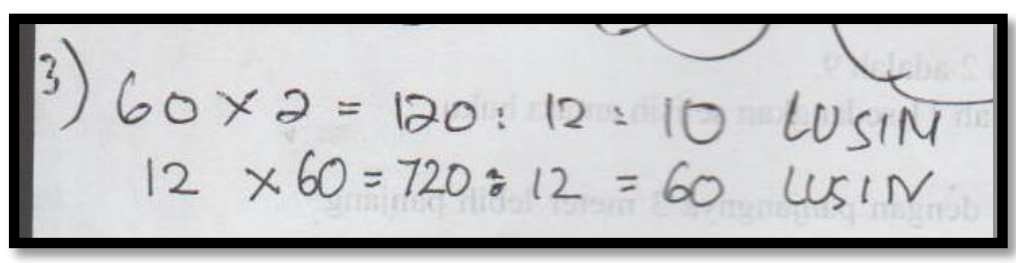

Figure 3. One of Student Answer to Problem No. 3

The indicator of mathematical communication ability in problem number three stated by Ansari (2012) is explaining problem situations by own words and doing the calculation. From figure 3 can be known that student can do the calculation but they can not explain clearly meaning of the number in their answer sheet. Also, students make the syrup and instant noodle in the same amount both on a dozen, even syrup and instant noodle are different type. Some students knew the way to solve the problem but can not state the reason about their way to answer the problem, this is probably because students find it difficult to express their idea or students not trained to giving a logical reason for the answer that they serve, it means students ability in explaining problem by own words and doing calculation is also weak.

Interviews were conducted with mathematics teachers of grade VII, concluded that the level of students' mathematical communication ability in the first grade have not developed optimally. Most students find difficulty in writing, explaining, and presenting mathematical ideas. Students lacking in interact to establishing communication with the teacher and other students. Interviews also conducted with some students, found that some students not interested in learning mathematics, they consider learning mathematics is difficult and all material about mathematics are hard to understand. In addition, they wanted the learning process is more varied, some of them want to have shared in learning, students which have a high ability want to help other students.

Lack of mathematical communication ability can lead to misunderstanding the mathematical concept or the problemand in the end students can not solve the problem, that is the reason needed to find an appropriate approach which will help student's to develop their mathematical communication ability and stimulating them to achieved their goals in learning. 
A good way of learning is learning that gives students full opportunity to express their opinions and ideas also alearning approach that is more effective, creative, and fun. On this basis, the authors try to apply cooperative learning talking stick type to see the improvement of students' mathematical communication ability.

Cooperative learning talking stick type has an aims to expand students' knowledge and accuracy in understanding a concept. As Suprijono (2009) said talking stick teaching methods encourage students to dare to express opinions. Agreed by Istarani (2012) that talking sticks learning model encourage students to dare to express their opinions, when teachers give an explanation about the material then students have time to read and write things they know after that the talking stick will be given to students and student that hold the stick must answer the question that teachers give or give the idea about thing that discussed, that is why cooperative learning talking stick type is one of an appropriate approach to develop student's mathematical communication through mathematical understanding which stimulated by the talking stick which going around the whole class to provide the opportunity for students to give their opinions. The syntax of talking stick approach in this research is modified from the syntactic of talking stick from Suprijono (2009) can be seen as follows:

1. Introduction

a. Delivering the learning objectives

b. motivating students

c. Delivering the learning method that will be used, which is talking stick type

d. Prepare the talking stick and the music

e. give students the SAS

2. Exploration and Elaboration

a. Asking students do SAS

b. Asking students to discuss with membersof their own group

c. Teachers guiding and motivate groups of studentswhile doing SAS

d. Teachers subsequently asked the students to close the book. Teachers take the stick which has been prepared in advance. The stick was given to one of the students

e. Students who received the baton required answering questions from the teacher, onwards. When the stick rolling of the student to other students and accompanied by music.

3. Confirmation

a. Teachers provide opportunities for students to reflect on the material that has been learned. Teacher gives a review of all answers given by the student

b. Together with the students formulate conclusions

4. Evaluation

a. Teachers give quizzes

b. Teachers evaluate learning outcomes

Based on the syntax, students are given the opportunity to discuss with their friends and then need to express their idea, opinion or the answer to the problem that teacher give. After that with the teacher discuss the material again to obtain a summary. The syntactic that Cooperative Learning Talking Stick type has, give a lot of opportunities for students to develop their mathematical communication ability in groups or their self. By using Cooperative Learning Talking Stick type concept made studied mathematics in a more meaningful way because the students are trying to understand the material by their own and then communicating back by giving the feedback. 
The indicators that used to see the mathematical communication ability in the concept of quadrilateral in this study are: (1) the ability of explaining mathematical problem into figure, (2) the ability of explaining problem situations by own words, and (3) the ability of stating mathematical problem into mathematical model and doing calculation to solve it (Ansari, 2012).

Based on the explanation, the issues to be discussed are the analysis indicators of students' mathematical communication ability that showed during the implementation of cooperative learning talking stick type and also to see if talking stick can be one of the learning approach that can be used to increase students' mathematical communication ability. The purpose of this study was to analyze the indicators of mathematical communication ability of students in class VII on one junior high school at Asahan-North Sumatera that appeared during the implementation of cooperative learning talking stick type and to find that cooperative learning talking stick type can increase students' mathematical communication ability.

\section{METHOD}

This research uses quasi-experiment with the post-test experimental class design with descriptive analysis of qualitative. In this research, the subject is one class in grade VII in one junior high school at Asahan. The independent variable in this study is cooperative learning talking stick type and the dependent variable is the students' mathematical communication ability. Primary data in this research is students' post-test results that made based on mathematical communication ability indicators that have been determined beforehand. The instrument in this research is post-test of mathematical communication skills that given at the end of the implementation of cooperative learning talking stick type. Post-test results were analyzed by determining the suitability of the students' answers to the indicators of the ability of mathematical communication that expected. From the data will be seen the students' average post-test results to be compared with mathematics minimum score that determined by the school to see the cooperative learning talking stick in improving students' mathematical communication ability.

\section{RESULTS AND DISCUSSION \\ Results}

Based on the results of the research that conducted in class VII in one junior high school at Asahan in the material quadrilateral with mathematical communication indicators used in the post-test are: (1) the ability of explaining mathematical problem into figure, (2) the ability of explaining problem situations by own words, and (3) the ability of stating mathematical problem into mathematical model anddoing the calculation to solve it, found that there are differences instudents' ways of answering the question even the treatment and the instrument used is same. The problem is Mr. Syamsuddin has 3 lands. The first land is side by side north and south to the second garden with a total area of $136 \mathrm{~m}^{2}$. The first land is a square with sides is $8 \mathrm{~m}$, the second land is a rectangular shape with a width $6 \mathrm{~m}$. The third garden is on the right side of the second land with also a rectangular shape and the width is $4 \mathrm{~m}$ and a length equal to first land sides plus the second land width. From the situation above; (a) by your own words find the length of the second land (give your reason); (b) Illustrate it into figure form; (c) Determine the mathematical expression to find the total area of land that owned by Mr. Syamsuddin and solve it.This question has all the three indicators that going to be analyzed. 
Question number 1 part a, the indicator that used is indicator number (2) the ability to explain problem situations by own words, found that there are differences in students' ways of answering the question even the treatment and the instrument used is same. There are some differences in students' ways of answer this part, as shown below:

caranya karena dikefatai L hetoun $1+$ luas kebun z bila disumlahkan Sama dengan $136 \mathrm{~m}^{2}$ i maka kita dap at mencap; Panjang dari keban 2(II) (lgn lara inenggulackan informas, dan $^{-}$L keban I dan Lhebun. D. Maka diremukas Caranya yaitu. dengan mengurangkain luas selurih dengan L. I

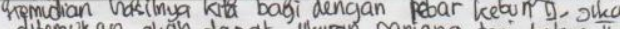
akan dapat thum paniang dari ketoun II

A absanya: Luas I tambah Luas II Sama dengan $136 \mathrm{~m}^{2}$. sisi $x$ sisi ditambah panfang $x$ lebar sama dengan 136 jadi. sisi hasilnya $64+$ Panjang $\times 6=136$ panjang cali engm sama denyan $136-64$ parjang kali enam $=7$ turuh pulundua dadi panjang dicari dari tuyuh puluh dua dibagi enam Pantangrya. hasiln ye tro

\section{B}

Figure 4. Student's Answer for Problem Number 1 Part (a)

For problem part $\mathrm{b}$ the indicator used is the ability to explain mathematical problem or situation into a figure. From 30 students there are different answers that found, the most answer shown in the figure below:

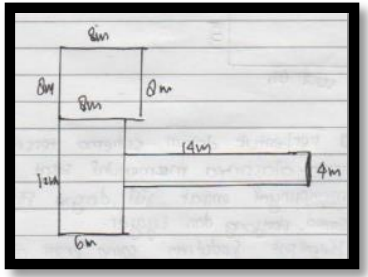

A

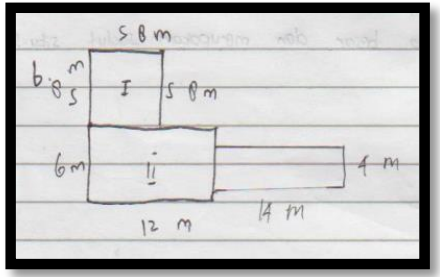

B

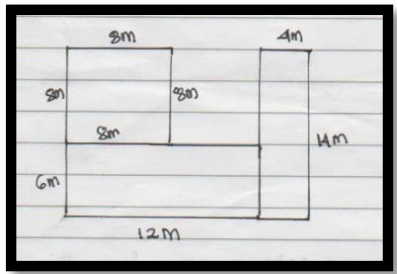

C

Figure 5. Students' Answer to the First Question Part (b)

For part c, the indicator that going to measure is the ability to state mathematical problem into a mathematical model and doing the calculation to solve it. The way students answer shown in picture below:

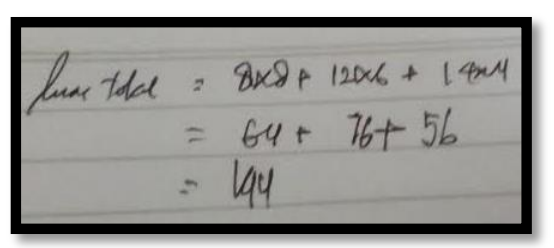

A

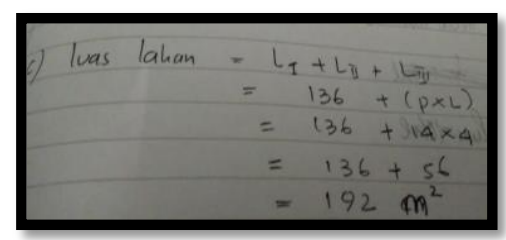

B

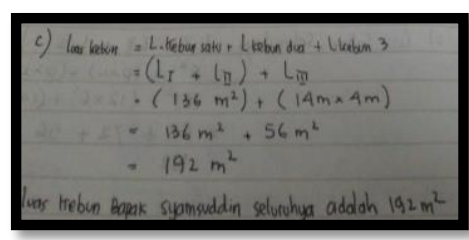

C

Figure 6. Students' Answer for Problem No.1 Part c. 


\section{Discussion}

In problem part a, as shown in the picture in discussion student (a) can state what on their mind on what need to do clearly but did not answer a full question, they do not find the length size of the second land and it make the answer just circulating in information that already given in the problem. This may be happening because the student already knows the concept of the problem and know how to solve it but student just has a habit of solving problem by using mathematical expression but cannot change that into their own words. Some students understand the concept or the problem it is just they still not able to make flow to conclude the answers to their own sentence. This kind of answer can also happen because students has difficulty in language, maybe students do not know which word they need to choose to lead the words to answer. The problem students can finish can happen also because they did not have interest in learn mathematics that has a lot of word, students already have paradigm that mathematics is all number.

In students (b) answer clearly show that student already know the concept and can communicate it rightly, even though the answer not perfect because students still use a mathematics expression such as subtraction and equal, but this kind of answer is close to what is wanted by the teacher as one of a good answer. The mathematical expression still in students answers in term of make situation into own words because students already familiarized with giving a good reason to complete an answer but still in not perfect ways. This can happen to because maybe students need more time to answer. Student (b) can clearly communicate what they want to tell and finish it until they found the answer. It is shown that some students that has a similar answer to the student (b) mathematical communication ability in part can make reason by using their own word is in good term.

In the learning process cooperative learning talking stick type all students have the same chance to give their thought, idea and also an opinion about the subject. Students which can make the right word or still stuttering in answer or give opinion getting help by their friend and also get the encourage from all class members such give applause. Student (a) has less confidence but when he gets courage from his classmate he can tell what on his mind and give a good way in answering the question, maybe in the exam he just does not know to choose the right words when he writes the answer. Researcher conduct an interview with student (a), when research asks if he understand the question number 1 part a, he can explain that the question is to find the length of the second land, he know how to solve it by using mathematical expression, he just not confidence to answer in words and loose what he want to write, that is why he just write the information on the problem. The researcher also conducts an interview with student (b), as the answer to her question she already knows the concept and the question, so she just writes down what she knows and what word she need to choose.

Able to use mathematical expression is also a good skill in completed the mathematical communication ability, but students need to familiarized with giving a reason in a problem so students can grave the ways to answer in their long time memory storage because they give a meaning to the answer. Some students that have an answer like student (a) need more training to make they accustomed with giving answer or reason by their own words.

In question part $b$, all students answer rightly in this question. It is shown that students already understand the concept of north and south, also the concept of the right side, this can happen because student already learns about the compass and understand it completely, also student 
clearly understand to differentiate square with a rectangle, even all students answer are differences in the way their answer this question. This differencesoccur because students have a different perception of the land shape, this happen because student has their own experience about land also the shape of square or rectangle.

Students that have an answer that similar to student (a) maybe wants to show that rectangle can be placed horizontally also vertical, it is just the partition between land I, I and III cannot see clearly, but the division of each length and side is good. Interview with student (a) found that her father has the land that has the same form as the land I and II. For students that have similar answer with student (b), they divided the land in good portion even for land I and II the size of $8 \mathrm{~m}$ and $6 \mathrm{~m}$ is same, maybe this happening because students do not pay full attention in subject scale when they learn in elementary school or student just assume them is different because they going to label it. But the students who answer similar like student (b) give a label for each land, it means students understand the position of each land. Interview with the student (b) found that she never known or see the land that has the same or similar form with the land in the problem, also the reason sided size of square and the width size of the rectangle is same because she just needs to figure it not to scale in the right measurement. For students that have similar answer with student (c) answer in a good way, they give all the size of the square and rectangle rightly and they use the information that the length of land III is total amount of sided of square and width of the land II rectangle and make the sided of square above the width of the land II, so they just draw length of land III in the same position with the incorporation of sided land I and width land II.

All students in this experiment answer the question as the teacher expected they to do. The mathematical communication ability in indicator the ability to explain mathematical problem into figure is in good term. This happen maybe because in the teacher-learning process of cooperative learning talking stick method all students have the same opportunity to draw the rectangular and presenting it in front of the class as personal or group, so the concept of square and rectangle already understood by them.

In part c, from 30 students more than half answer this question rightly. Some students do wrong in the calculation and the other did not finish the calculation and did not make the mathematical model or expression that describe the problem. This may happen because students did not understand the problem or student do not get the concept of the problem.

As for students which have a similar answer to student (a), they do the calculation wrongly and did not state the mathematical model that shown the question. This may happen because students feel the need to finish the test fast and make they lose their concentration. In the learning process of cooperative learning talking stick type this kind of problem might happen because students have more time to talk about their opinion but a little time to write what is on their mind. As shown in student (a) answer, he understands the problem which is to find the total area of Mr. Syamsudiin land, maybe he thinks is no need to made the mathematical expression because he already knew, even though the mathematical expression is in the question. Interview conduct with student (a) found that he feels do not need to explain more because he already knows the way to find the total land area and for the miscalculating, he states that he rushing in calculate it because of he thinks the time is almost done. It is shown that students with a similar answer to student (a), their mathematical communication ability in indicator the ability to state mathematical problem into a mathematical model and doing the calculation to solve it is in an unsatisfactory manner. 
For students that have a similar answer to student (b) clearly, understand the problem and knew how to solve it. They state the mathematical expression rightly to describe the way to find Mr. Syamsuddin total land area by adding all the area from land I, II and III. They also use the information rightly that the total amount of land I and II already knew so they just need to calculate the area of land III and adding it together, this may happen because students understand the problem and all the information that given. This also can happen because maybe student already do this kind of problem before in their elementary school or they have experienced to calculate the total amount of area before. This also can be the effect of learning by using cooperative learning talking stick type, in the learning process when students given the SAS they found the material by their self and also try to understand it fully to be able to present it when the talking stick come to them. Interview with student (b) found that she already knew the total amount of land I and II, so she thinks it does not need to calculate it again, and she already has similar problem before.

The same for students that have the similar answer to student (c), they clearly state the mathematical model to find the total area of the land. They do the checking part by calculation the land area one by one, this also can be the effect learning by using cooperative learning talking stick type in part when the teachers provide opportunities for students to reflect on the material that has been learned and the teacher gives a review of all answers given by the student. They also give the explanation at the end of their answer to conclude the calculation. This kind of answer might happen same as the student (b) because students that answer similarity with student (c) already understand the problem and also the concept. Also, this can happen because students already experienced this kind of problem before. When students do the checking part by calculating it one by one the area is because they do not want to do the wrong step. The interview conducted with student (c) found that he wants to check again is he do the right calculation when he finds the length of land II, and he wants to show the teacher that he understands the different of square and rectangle also the formula that uses for each of them. The answer of student (b) and (c) are the closest to answer that teacher expected they to do.

Based on students answer from the three indicator measured after the implementation of cooperative learning talking stick type approach can be sorted from easiest indicator to the most difficult for students in question are as follows: (1) the ability of explaining mathematical problem into figure, (3) the ability of stating mathematical problem into mathematical model and doing the calculation to solve it and (2) the ability of explaining problem situations by own words. In other word in the learning process noted that the indicators the ability to make the situation into a picture is the highest position. It can be concluded most students master this indicator, and the indicators that difficult for the student is giving a reason or evidence for the correctness of the solution from a situation.

To see the effect after implementation of cooperative script talking stick type approach can effect to students' mathematical communication ability researcher compare the average of students' test value with the minimum mathematics score that assigned by the school. Minimum score assigned by the school for mathematics is 72 , from the data that researcher get found the average score of the students is 74.91, with maximum score is 91.67 and minimum score is 61.11 , it shown that students mathematical communication ability by using cooperative learning talking stick type approach is more high than the minimum score even though the different did not so big. From all data also found that 17 students pass the minimum score, 5 students score is exactly the minimum score and 8 students did not pass the 
minimum score, it is shown that cooperative learning talking stick type has a good impact on students' mathematical communication ability but not the really fine approach to use.

\section{CONCLUSION}

Analysis of students' mathematical communication ability after the implementation of Cooperative learning talking stick type show that there are the differences in students' characteristics ways of answering the mathematical problem. Other than that found that studentsmost difficult indicator is explaining the way to answer the problem situations by own words. It is also in line with the opinion of Hidayat (2017) who argued that one's difficulty in explaining the process of the problem given due to the habit of the less innovative way of teaching.

\section{REFERENCES}

Ansari, B. I. (2012). Komunikasi Matematik Dan Politik Suatu Perbandingan: Konsep dan Aplikasi. BandaAceh: Penerbit PeNA

Baroody, A. J. (1993). Problem Solving, Reasoning, and Communicating K-8 Helping Children Think Mathematically. New York: Merril An In Print of Macmillan Publishing Company

Clark, K. K., Jacobs, J., Pittman, M. E., \& Borko, H. (2005). Strategies for building mathematical communication in the middle school classroom: Modeled in professional development, implemented in the classroom. Current Issues in Middle Level Education, 11(2), 1-12.

Cobb, P., Yackel, E., \& Wood, T. (1992). Interaction and learning in mathematics classroom situations. Educational studies in mathematics, 23(1), 99-122.

Depdiknas, R. I. (2006). Peraturan Mendiknas Nomor 22 Tahun 2006 Tentang Standar Isi. Jakarta: Depdiknas.

Hidayat, W. (2017). Adversity Quotient dan Penalaran Kreatif Matematis Siswa SMA dalam Pembelajaran Argument Driven Inquiry pada Materi Turunan Fungsi. KALAMATIKA Jurnal Pendidikan Matematika, 2(1), 15-28.

Istarani (2012). 58 Model Pembelajaran Inovatif. Medan: Media Persada

National Council of Teachers of Mathematics (1989). Curriculum and evaluation standards for school mathematics. Reston, VA: NCTM.

National Council of Teachers of Mathematics (2000). Principles and standards for school mathematics. Reston, VA: NCTM

National Middle School Association (2004). Position paper of the National Middle School Association middle level curriculum: A work in progress. Westerville, OH: NMSA

Pugalee, D. K. (2001). Using communication to develop students' mathematical literacy. Mathematics Teaching in the Middle School, 6(5), 296.

Secretary's Commission on Achieving Necessary Skills (1991). What work requires of schools: A SCANS report for America 2000. Washington, DC: U.S. Department of Labor. 
194 Sari, Analysis of Students' Mathematical Communication Ability by Using Cooperative ...

Lin, C. S., Shann, W. C., \& Lin, S. C. (2008). Reflections on mathematical communication from Taiwan math curriculum guideline and PISA 2003. Retrieved from http://www.criced.tsukuba.ac.jp/math/apec/apec2008/papers/PDF/

16.Lin_Su_Chun_Taiwan.pdf

Suprijono, A. (2009). Cooperative Learning Teori \& Aplikasi Paikem. Yogyakarta: Pustaka Pelajar. 